\title{
5237 Sayılı Türk Ceza Kanunu’nda Siyasi Hakların Kullanılmasının Engellenmesi Suçu
}

\author{
Hüseyin ERTUĞRUL \\ Kırşehir Ahi Evran Üniversitesi \\ hertugrul83@ahievran.edu.tr \\ ORCID: 0000-0003-1372-2451
}

\begin{tabular}{lrr} 
Derleme Makalesi & DOI: $10.31592 /$ aeusbed.723588 \\
\hline Geliş Tarihi: 20.04 .2020 & Revize Tarihi: 26.06 .2020 & Kabul Tarihi: 08.07 .2020
\end{tabular}

\section{Atıf Bilgisi}

Ertuğrul, H. (2020). 5237 sayılı Türk Ceza Kanunu'nda siyasi hakların kullanılmasının engellenmesi suçu. Ahi Evran Üniversitesi Sosyal Bilimler Enstitüsü Dergisi, 6(2), 377-389.

\section{ÖZ}

\begin{abstract}
1 Haziran 2005 tarihinde yürürlüğe giren 5237 sayılı Türk Ceza Kanunu'nun 114. maddesinde, siyasi hakların kullanılmasını engellemeye yönelik bazı fiiller suç olarak düzenlenmiştir. Böylelikle kanun koyucu, kişilerin siyasi hak ve hürriyetlerini önemli ölçüde güvence altına almak istemiştir. Madde metninde, siyasi hakların kullanılmasının engellenmesi başlığı altında, bir siyasi parti veya bir kamu görevi ile ilgili kullanılacak siyasi haklara yönelik zorlama fiilleri yaptırıma bağlanmıştır. Böylelikle suçun kanuni tanımında sayılan bir siyasi parti veya bir kamu görevi ile ilgili siyasi haklar, koruma altına alınmışken; bunun dışında yer alan siyasi haklar, koruma altına alınmamıştır. Başka bir ifadeyle, belirli siyasi faaliyetlerin engellenmesi suç olarak düzenlendiğinden, diğer siyasi hakların kullanılmasının engellenmesi, bu suç kapsamı dışında kalacaktır. Bu durumun madde başlığ 1 ile değerlendirildiğinde, kanun tekniğine uygun olmadığı mevcut eleştiriler arasındadır. Yargıtay'ın vermiş olduğu kararlarda söz konusu suçun unsurları ile ayrıntılı açıklamalara yer verilmiş ve aynı hukuki değeri koruyan farklı suç tanımları arasında fikri içtima kurallarının uygulanması gerektiği ifade edilmiştir. Kanaatimizce burada özel norm-genel norm tartışması yapılması gerekmektedir.
\end{abstract}

Anahtar Kelimeler: Siyasi hak, suç, ceza, tehdit, cebir.

\section{The Crime of Preventing The Use of Political Rights}

\begin{abstract}
In Article 114 of the Turkish Penal Code No. 5237, which came into force on 1 June 2005, some acts aimed at preventing the exercise of political rights are regulated as crimes. The objective of the new law, the legislator wanted to secure the political rights and freedoms of the people.In the text of the article, under the title of preventing the use of political rights, enforcement acts against political rights to be used in relation to a political party or a public office are sanctioned. Thus, while political rights related to a political party or a public duty, which are considered in the legal definition of crime, are under the protection of law; apart from that, rest of political rights are not protected. In other words, since the blocking of certain political activities is regulated as a crime, preventing the use of other political rights will be excluded from this crime. When this situation is evaluated with the item title, it is among the current criticisms that it is not suitable for the law technique. In the judgements of the relevant Department of the Supreme Court, the detailed explanations about the elements of the crime were included and it was stated that the rules of intellectual interaction should be applied among the different crime definitions that protect the same legal value. In our opinion, an evaluation of special norm and general norm should be discussed here.

Keywords: Political right, crime, punishment, threat, force.
\end{abstract}

\section{Giriş}

Hak; lügat manası itibariyle, doğruluk, özgürlük, adalet ve hukuka uygunluk manasına gelmekle birlikte; terim manasıyla, kişilere hukuk düzeni tarafından takdir edilen ve bazı edimlerin yerine getirilmesini isteme yetkisi veren menfaatler anlamına gelmektedir (Türkçe Sözlük, 2017; Y1lmaz, 2011). Esasen hak kavramı, hürriyetin hukuk düzenince tanınmış halini ifade etmektedir. Başka bir ifadeyle insan hürriyeti, hukuk düzenince korunursa hak haline gelmektedir (Gözler, 2017). Hak, bir hürriyetin sağlanması için kişiye anayasa ve kanunlar ile tanınmış yetkilerdir. Hak, hem bir yetkiyi ifade etmekte, hem de bu yetki, hukuk tarafından koruma altına alınmaktadır (Küçük, 2013).

Haklar üzerinde öğretide kabul gören sınıflandırma, Georg Jellinek'in yapmış olduğu üçlü ayrımdır (Aydın, 2013). O'na göre, temel hak ve hürriyetler; devlet ile kişi arasındaki ilişkinin durumuna göre, kişi hakları (negatif statü hakları), sosyal ve ekonomik haklar (pozitif statü hakları) ve siyasi haklar (aktif statü hakları) olmak üzere üçe ayrılmaktadır (Aydoğdu, 2017; Gözler, 2017; Küçük, 2013). 
Nitekim 2709 sayılı Türkiye Cumhuriyeti Anayasası'nda da bu ayırıma göre temel hak ve hürriyetler sınıflandırılarak düzenlenmiştir. 1982 Anayasası'nın ikinci kısmında, "Temel Haklar ve Ödevler" başlığı altında, m.17-40 arasında kişi hakları, m.41-65 arasında sosyal ve ekonomik haklar, m.66-74 arasında siyasi haklar yer almaktadır.

Siyasi haklar, kişilerin devlet yönetimine katılma imkânını sağlayan temel hak ve özgürlüklerdir. Nitekim siyasi haklar, "katılma hakları" ya da "aktif statü hakları" olarak da isimlendirilmektedir (Aydoğdu, 2017; Gözler, 2017; Küçük, 2013). Siyasi haklar, temel olarak 1982 Anayasası'nın 66. ve devamı maddelerinde ifade edilmiştir. Buna göre, seçme, seçilme ve siyasi faaliyette bulunma hakk1 (m.67), parti kurma, partilere girme ve partilerden ayrilma hakk1 (m.68), kamu hizmetlerine girme hakkı (m.70), vatan hizmeti (m.72), dilekçe hakkı (m.74) siyasi haklar içerisinde yer almaktadır.

Bu makalede, Anayasa'da da teminat altınan siyasî hakların bazı kullanım türlerine yönelik fillerin suç haline getirilmesi konusu ele alınacaktır.

\section{Türk Ceza Kanunu'nda İlgili Düzenleme}

5237 sayılı Türk Ceza Kanunu'nda siyasi haklara karşı işlenen fiillerin bir bölümü, kanunun "Özel Hükümler" başlıklı ikinci kitabının "Kişilere Karşı Suçlar"1 düzenleyen ikinci kısmının "Hürriyete Karşı Suçlar" başlığını taşıyan yedinci bölümünde düzenlenmiştir. Bu yedinci bölümde, tüm siyasi haklar değil, belirli siyasi haklar koruma altına alınmıştır. Katıldığımız görüşe göre bu suç tanımının Türk Ceza Kanunu'nun Millete ve Devlete Karşı Suçlar bölümünde düzenlenmesi daha uygun olacaktır. Çünkü bir siyasal hakkın ihlal edilmesi, devletin siyasal fonksiyonlarını yerine getirmesini engellemekte ve bu nedenle devletin temel düzenine yönelik bir suç söz konusu olmaktadır (Tezcan, Erdem ve Önok, 2014).

Bu bölümde inceleme konumuz "siyasi hakların kullanılmasının engellenmesi suçu" dışında, dilekçe hakkının kullanılmasının engellenmesi (m.121) fiili de suç olarak düzenlenmiştir. Şu halde Türk Ceza Kanunu (TCK) iki suç tanımını, doğrudan siyasi hakları koruma altına almaktadır. Bunlar "siyasi hakların kullanılmasının engellenmesi" ve "dilekçe hakkının kullanılmasının engellenmesi" suçlarıdır.

Türk Ceza Kanunu'nda düzenlenen bu suç tanımlarından başka bazı siyasi haklara yönelik fiiller ise, dernek, sendika, toplantı ve gösteri yürüyüşlerini düzenleyen özel kanunlarla koruma altına alınmıştır. (Örneğin, 298 sayılı Seçimlerin Temel Hükümleri ve Seçmen Kütükleri Hakkında Kanunu m.133 vd; 2911 sayılı Toplantı ve Gösteri Yürüyüşleri Kanunu m.31 vd.; 5232 sayılı Dernekler Kanunu, m.32). (Siyasi haklara ilişkin bazı suçlar da Siyasi Partiler Kanununun 111., 112., 113., 114., 116. ve 120. maddelerinde düzenlenmiştir)

\section{Suçun Kanuni Tanımı}

Söz konusu suçun kanuni tanımının iki ayrı dönemde incelenmesi, karşılaştırma yapılabilmesi bakımından önem arz etmektedir.

\section{Mülga 765 sayılı Türk Ceza Kanunu Dönemi}

1.3.1926 tarih ve mülga 765 sayılı Türk Ceza Kanunu'nun ikinci kitabının, ikinci kısmının birinci bölümünde "Siyasi Hürriyet Aleyhine Cürümler" başlıklı 174. maddesi şöyleydi:

\footnotetext{
"Her kim şiddet veya tehdit göstererek veya nümayiş veya gürültü yaparak birini tamamen veya kısmen siyasî haklarını kullanmaktan menederse kanunun başka ceza vermediği hallerde yedi aydan otuz aya kadar hapis ve on beş liradan elli liraya kadar ağır cezayi naktî ile cezalandırılır. Eğer fail, Devlet memurlarından olup da memuriyeti nüfuzunu suiistimal suretile bu cürmü işlemiş bulunursa
} 
bir seneden beş seneye kadar hapsolunur. Ayrıca bir seneden üç seneye kadar memuriyetten mahrumiyet cezasına da uğrar."

Görüleceği üzere, burada eşit seviyede siyasi hakların koruma altına alınması söz konusudur. Çünkü kanuni tanımda hangi hakların siyasi hak olarak nitelendirileceği hususunda bir açıklık bulunmamaktadır. Esasen bu durum, belirlilik ilkesine ve suçta ve cezada kanunilik ilkesine uygun düşmemektedir. Yani ceza hukukunun güvence fonksiyonunu oluşturan bu ilkeler gereği, suçun kanuni tanımının açık ve belirli olması gerekir. Soyut olarak hukuka aykırı davranışların ceza yaptırımına bağlanması kanunilik ilkesine aykırılık teşkil etmektedir (Özgenç, 2019).

\section{7 sayılı Türk Ceza Kanunu Dönemi}

5237 sayılı TCK'da, "siyasi hakların kullanılmasının engellenmesi” suçu, 114. maddede, şu şekilde düzenlenmiştir:

“(1) Bir kimseye karşı; a) Bir siyasi partiye üye olmaya veya olmamaya, siyasi partinin faaliyetlerine katılmaya veya katılmamaya, siyasi partiden veya siyasi parti yönetimindeki görevinden ayrılmaya, b) Seçim yoluyla gelinen bir kamu görevine aday olmamaya veya seçildiği görevden ayrılmaya, zorlamak amacıyla, cebir veya tehdit kullanan kişi, bir yıldan üç yıla kadar hapis cezası ile cezalandırılır. (2) Cebir veya tehdit kullanılarak ya da hukuka aykırı başka bir davranışla bir siyasi partinin faaliyetlerinin engellenmesi halinde, iki yıldan beş yıla kadar hapis cezasına hükmolunur."

İfade ettiğimiz üzere, mülga 765 sayılı Türk Ceza Kanunu'nun 174. maddesinden farklı olarak, hangi siyasi hakların korunduğu açıkça belirtilmiş olup, önceki düzenlemede açıklanmadan bırakılan "siyasi haklar" ibaresi nedeniyle oluşan belirsizlik ortadan kaldırılmıştır. Nitekim Yargıtay da bir kararında katıldığımız şu ifadelere yer vermiştir:

“Bu yasal düzenlemede, önceki yasal düzenleme olan 765 sayılı Türk Ceza Kanununun 174. maddesinden farklı olarak, hangi hakların siyasi hak olarak nitelendirildiği açıkça belirtilmiş, önceki düzenlemede açıklanmadan bırakılan "siyasi haklar" ibaresi nedeniyle oluşan belirsizlik ortadan kaldırılmıştır” (Yargıtay, 4. Ceza Dairesi, Esas:2014/585, Karar:2016/9881, Karar Tarihi: 12.05.2016).

\section{Korunan Hukuki Değer}

Söz konusu suç tanımıyla korunan hukuki değer, öğretide birinci fikra için, "kişilerin siyasal hakları" olduğu; ikinci fikradaki düzenleme için ise, korunan hukuki değerin "kolektif siyasi haklar" olduğu ifade edilmektedir (Özbek, 2008). Yargitay da bu suç kapsamında korunan hukuki değeri, şu şekilde ifade etmiştir:

\footnotetext{
"Siyasi hakların kullanılmasının engellenmesi suçu ile korunmak istenen hukuki değer, birinci fikra açısından, bir kimsenin bireysel olarak bir siyasi partiye girme veya girmeme, faaliyete katılma veya katılmama, seçim yoluyla gelinen bir kamu görevine aday olma ve o görevden ayrılma iradesidir. Yani bireysel siyasi hakların kullanılması özgürlüğüdür. İkinci fikra açısından ise Anayasal güvence altına alınan siyasi partilerin faaliyet özgürlüğ̈̈dür" (Yargitay, 4. Ceza Dairesi, Esas: 2014/585, Karar: 2016/9881, Karar Tarihi: 12.05.2016).
}

Kanaatimizce, TCK m.114/1'de düzenlenen suç tanımıla korunan hukuki değer, (a) bendi açısından, 1982 Anayasası'nın 68. maddesinde düzenlenen "parti kurma, partilere girme ve partilerden ayrılma" hakkıdır. (b) bendi ise, yine 1982 Anayasası'nın 70. maddesinde düzenlenen "kamu hizmetlerine girme" hakkıdır. Keza TCK m. 114/2'de düzenlenen suç tanımıyla korunan hukuki değer ise, 1982 Anayasası'nın 68. maddesinin 3. fikrasında düzenlenen anayasa ve kanunlara uygun olarak "siyasi partilerin faaliyetlerini sürdürme" hakkıdır. 


\section{Suçun Unsurları}

Suçun unsurları konusunu; suçun maddi unsurları, manevi unsurları ve suçun hukuka aykırılık unsuru olmak üzere üç başlık altında incelemek gerekmektedir.

\section{Suçun Maddi Unsurları}

Fiil, illiyet bağı, netice, suçun konusu, fail ve mağdur kavramları bir suçun maddi unsurlarını oluşturmaktadır.

\section{Fiil}

Türk ceza hukukunda fiil, kişinin iradesiyle hakim olduğu, belli bir neticeyi gerçekleştirmeye matuf ve harici dünyada cereyan eden bir davranıştır (Özgenç, 2019). TCK'nın 114. maddesinde, siyasi hakların kullanılmasının engellenmesi başlığı altında, her birinin koruduğu farklı hukuki değerleri olan üç ayrı fiil düzenlenmiştir. Her bir fiilde ayrı hukuki değerler korunduğu için, üç ayrı suç tanımı mevcuttur (Hafizoğulları ve Özen, 2015). Nitekim TCK m.114'ün madde gerekçesinde yer alan aşağıdaki ifadeler, düşüncemizi desteklemektedir (TBMM, Dönem:22, Yasama Y11ı:2, Sıra Sayısı: 664, s.524):

"Maddenin birinci fikrasının (a) bendine göre ... suç oluşturmaktadır. Birinci fikranın (b) bendinde

... suç olarak tanımlanmıştır. Maddenin ikinci fikrasında ... ayrı bir suç olarak tanımlanmıştır."

Bu suçların ikisi, madde metninin ilk fikrasında düzenlenirken; diğeri, ikinci fikrada cebir veya tehdit kullanılarak ya da hukuka aykırı başka bir davranışla bir siyasî partinin faaliyetlerinin engellenmesi şeklinde düzenlenmiştir. Kanunun bu düzenlemesine göre, bu üç suç tanımında yer alan fiilleri, üç ayrı başlık altında incelemeye çalışacağız.

\section{Türk Ceza Kanunu m.114/1(a) Bendinde Düzenlenen Fiil}

TCK m. 114/1(a) bendinde, bir kimseye karşı cebir veya tehdit kullanılarak,

-Bir siyasî partiye üye olmaya veya olmamaya,

-Siyasî partinin faaliyetlerine katılmaya veya katılmamaya,

-Siyasî partiden veya siyasî parti yönetimindeki görevinden ayrılmaya zorlamak amaciyla işlenen fiiller, bu suçu oluşturmaktadır. Burada altı farklı seçimlik hareket düzenlenmiştir. Bunlardan birinin cebir veya tehdit kullanılarak gerçekleştirilmesi halinde suç tamamlanmış sayılacaktır.

Mesela Yargıtay’ın şu kararını örnek olarak vermemiz mümkündür:

\footnotetext{
"Sanığın, 12.06.2011 tarihinde yapılacak genel seçimlere yönelik olarak pazar yerinin girişinde bir siyasi partinin tanıtım ve üyelik çalışmasını yapan katılan ... ve tanık ...'un bulunduğu standa doğru "Sizleri yok edeceğiz, bitireceğiz, sizlere tahammül edemiyoruz" diyerek seslenip tehditte bulunmasını takiben siyasi parti standını tekmeleyerek cebir gerçekleştirmesinden sonra ...(eylemleri TCK m.114/1'deki suçu oluşturmaktadır.)" (Yargıtay, 4. Ceza Dairesi, Esas: 2014/585, Karar: 2016/9881, Karar Tarihi: 12.05.2016).
}

Hemen ifade edelim ki, bu suç tanımında yer alan seçimlik hareketler arasında, siyasi partideki görevinde kalmaya zorlama veya bir siyasi partiye oy kullanılması yönünde zorlama fiilleri yer almamaktadır. Dolayısıyla bu yönde yapılan zorlamalar mesela partisindeki görevinden istifa etmek isteyen birine, görevinde kalması için yapılan zorlama ya da belirli bir partiye oy verilmesi için bir tehditin yapılması bu suç kapsamında değerlendirilemeyecektir. Somut olaya göre salt tehdit (TCK, m.106), şantaj (TCK, m.107) veya cebirden (TCK, m.108) sorumluluk söz konusu olabilecektir. 


\title{
Türk Ceza Kanunu m.114/1(b) Bendinde Düzenlenen Fiil
}

Maddenin aynı fikrasının (b) bendinde ise, bir kimseye karşı cebir veya tehdit kullanılarak,

-Seçim yoluyla gelinen bir kamu görevine aday olmamaya veya seçildiği görevden ayrılmaya zorlamak amacıyla işlenen fiiller, bu bentteki suçu oluşturmaktadır.

Dikkat edilirse yer alan seçimlik hareketler kişilerin kamu hizmetine girme hakkının engellenmesine yöneliktir. Dolayısıyla mevcut bir kamu hizmetinde kalmaya yönelik zorlama fiili bu suç kapsamında değerlendirilmeyecek; somut olaya göre, tehdit, şantaj veya cebir suçlarından bir sorumluluk söz konusu olabilecektir.

Maddenin birinci fikrasında düzenlenen her iki bentte de fiillerin cebir veya tehdit ile gerçekleştirilmesi gerekmektedir. Mesela "hile" ile bu seçimlik hareketlerin gerçekleştirilmesi halinde de bu suç oluşturmayacaktır. Duruma göre hilenin unsur olarak yer aldığı suç tanımları, mesela dolandırıcılık suçu söz konusu olabilecektir.

Keza yine her iki bentte, cebir veya tehdide maruz kalan kişinin siyasî partiye üye olması veya olmaktan vazgeçmesi, siyasî partinin faaliyetlerine katılması veya katılmaktan vazgeçmesi ya da siyasî partiden veya siyasî parti yönetimindeki görevinden ayrılması, seçim yoluyla gelinen bir kamu görevine aday olmaması veya seçildiği görevden ayrılması gerekmemektedir. Bu amaçlarla, kişiye karşı cebir veya tehdit kullanılması, söz konusu suç tamamlanmış gibi cezalandırılabilmek için yeterlidir. $\mathrm{Bu}$ bakımdan maddenin gerekçesinde ve öğretide söz konusu suç tanımlarının, birer teşebbüs suçu niteliği taşıdığı kabul edilmektedir (Özbek, Kanbur, Doğan, Bacaksız ve Tepe, 2015; Tezcan, Erdem ve Önok, 2014).

\section{Türk Ceza Kanunu m.114/2 Fıkrasında Düzenlenen Fiil}

Bu fikrada yaptırım altına alınan fiil, cebir veya tehdit kullanılarak ya da hukuka aykırı başka bir davranışla siyasî partinin faaliyetlerinin engellenmesi oluşturmaktadır. Yani cebir veya tehdit dışında hukuka aykırı bir davranışla mesela hile ile bu suçun işlenmesi mümkündür. Fakat her ihtimalde, suçun oluşması için siyasî partinin faaliyetlerinin engellenmesi gerekmektedir. Dolayısıyla bu suç neticeli bir suçtur. Başka bir ifadeyle, maddenin 1. fikrasında düzenlenen suç tanımları, teşebbüs suçu niteliğindeyken; ikinci fikrada düzenlenen suç tanımı neticeli suç niteliğindedir. Dolayısıyla cebir veya tehdit kullanılmış olmasına rağmen siyasi parti faaliyetlerine devam edebilmiş ise, artık 114/2'ye teşebbüsten dolayı bir sorumluluk söz konusu olacaktır.

Yargıtay, TCK m.114'de düzenlenen suç tanımlarının maddi unsurlarını şu şekilde açıklamaktadır:

\begin{abstract}
"Suçun birinci fikradaki halinin maddi unsuru, cebir veya tehdit ile bir siyasi partiye üye olmaya veya olmamaya, siyasi partinin faaliyetlerine katılmaya yahut katılmamaya, siyasi partiden veya siyasi parti yönetimindeki görevinden ayrılmaya zorlanmak, seçim yoluyla gelinen bir kamu görevine aday olmamak için veya seçildiği görevden ayrılmaya zorlanmaktır. Failin bu amaçla cebir ve tehdide başvurması yeterli olup, ayrıca bunun sonucunda, yukarıda sayılan hakların kullanılmasının engellenmiş olması gerekmez. Engelleme eyleminin cebir ve tehditle gerçekleştirilmesi gerektiğinden, bu suç, bağlı hareketli bir suçtur. İkinci fikradaki halinin maddi unsuru ise cebir veya tehdit ya da hukuka aykırı başka bir davranışla, mevzuata uygun olarak kurulmuş bir siyasi partinin faaliyetlerinin engellenmesidir. Bu suçun oluşumu için birinci fikradan farklı olarak hakkın kullanılmasının engellenmiş olması gerekir. Siyasi partinin faaliyetinden maksat, siyasi partilerin mevzuata ve tüzüklere uygun olarak gerçekleştirdikleri her türlü faaliyettir (Yargitay, 4. Ceza Dairesi, Esas:2014/585, Karar:2016/9881, Karar Tarihi: 12.05.2016).”
\end{abstract}

TCK m.114'te düzenlenen tüm suçlar, bağlı hareketli suçlardır. Fakat ilk fıkrasında düzenlenen suçlarda, mağdura karşı mutlaka cebir veya tehditin kullanılmış olması gerekir, ikinci fikradan farklı olarak "hukuka aykırı başka bir davranışla" mesela hile ile bu suçların işlenmesi mümkün değildir. Fakat 
ikinci fikrada bu mümkün olarak geniş kapsamlı düzenlenmiştir (Tezcan, Erdem ve Önok, 2014; Özbek $\mathrm{vd}, 2015)$.

\section{Netice}

Netice kavramı, ceza hukukunda hareketin dış dünyada meydana getirdiği değişikliği ifade etmektedir (Bahri ve Erdem, 2013). TCK'nın 114. maddesinin 1. fikrasındaki fiiller, sırf hareket suçları mahiyeti taşırken; ikinci fikrada düzenlenen suç tanımı, neticeli suçtur.

Birinci fikrada, siyasi hakların kullanılmasının engellenmesi suçunun tamamlanmış olabilmesi için, kişinin ilgili siyasi hakkını kaybetmiş olması gerekmemektedir. Bu yönde yapılan zorlama suçun tamamlanması için yeterlidir. İkinci fikrada ise, suçun tamamlanması için, bir siyasi partinin faaliyetlerinin engellenmesi gerekmektedir.

\section{Suçun Konusu}

Suçun konusu, hareketin yöneldiği kişi ya da şeyi ifade etmektedir. Bu bağlamda, siyasi hakların engellenmesi suçunun konusu, TCK'nın 114'üncü maddesinin fikralarına göre farklılık arz etmektedir. İlk fikrada mağdurun ilgili siyasi hakları, ikinci fikrada ise siyasi partinin engellenen faaliyetleri suçun konusunu oluşturmaktadır (Artuk, Gökcen ve Yenidünya, 2014).

\section{Fail}

Fail, suçun kanuni tanımındaki hareketi gerçekleştiren gerçek kişidir (Özbek vd, 2015). Söz konusu suçun seçimlik hareketlerinin faili olabilmek için, gerçek kişi olabilmek yeterlidir. Yani bu fiillerin işlenmesinde, özel bir faillik vasfı söz konusu değildir.

Eğer bu suç birden fazla kişi ile birlikte gerçekleştirilirse, TCK'nın 119. maddesinin 1. fikrasının (c) bendi gereği cezada artırıma gidilecektir. Yargıtay, bunun göz ardı edilmesini bozma nedeni olarak değerlendirmektedir. Yargıtay'ın şu kararını örnek olarak vermemiz mümkündür:

\footnotetext{
“Sanığın ... arkasından gelen suça sürüklenen oğlu ... Uyguntürk ve kimliği belirlenemeyen ancak sanı̆̆ın çalışanı olduğu tahmin edilen bir başka kişi hakkında da aynı suç nedeniyle ... Cumhuriyet Başsavcılığınca ayırma kararı verilerek ... nolu dosya üzerinden soruşturma yapıldığının anlaşılması karşısında, söz konusu dosyalar getirtilip incelenerek, sonucuna göre sanık hakkında TCK'nın 119/1 c maddesinin uygulanıp uygulanmayacağının tartışılmaması hükmün bozulmasını gerektirmiştir (Yargitay, 4. Ceza Dairesi, Esas: 2014/585, Karar: 2016/9881, Karar Tarihi: 12.05.2016)."
}

\section{Mă̆dur}

Mağdur, suçun kanuni tanımında haksızlığa uğramış gerçek kişi demektir (Özgenç, 2019). Söz konusu suçun mağduru ise, siyasi hakkı kullanma hak ve ehliyetine sahip gerçek kişidir. Bu kişinin de Türkiye Cumhuriyeti vatandaşı olması gerekmektedir. Ayrıca kamu hizmetinden yasaklı kişilere örneğin TCK m.53 gereği ilgili siyasi hakları kullanamayanlara karşı bu suç işlenemez (Aydoğdu, 2017).Yargıtay da benzer şekilde söz konusu suçun mağdurunu şu şekilde açıklamıştır:

"ilk fikrada düzenlenen suçun mağduru herkes olamaz. Ancak, gerçek kişinin on sekiz yaşını bitirmiş, Türk vatandaşı olması, aynı zamanda bu kişinin kamu görevlisi olmaması ve siyasi hakları kullanmaktan yasaklı bulunmaması, 2820 sayılı Siyasi Partiler Kanununun 11. maddesinin 2, 3, 4. fikralarında sayılan suçlar ile terör eyleminden mahkûm olmamış olması gerekir. Ayrıca TCK'nın 53. maddesine göre bir suça mahkumiyetin sonucu olarak failin belli hakları kullanmaktan yoksun bırakılması durumunda da bu süre içerisinde bu kimselerin bu suçun mağduru olma imkânı bulunmamaktadır. İkinci fikrada düzenlenen suçun mağduru ise, siyasi partilerin yöneticileridir. Suçtan zarar gören de siyasi partilerdir. Siyasi partiler, 2860 sayılı Kanunun 8. maddesi uyarınca bildirim ve belgelerini İçişleri Bakanlığına vermeleriyle tüzel kişilik kazanırlar. Siyasi partilerin 
tüzel kişilik kazanmaları yeterli olup, seçime katılma yeterliğine sahip olmaları gerekli değildir (Y.,

4. CD, Esas:2014/585, Karar:2016/9881, Karar Tarihi: 12.05.2016).”

\section{Suçun Manevi Unsuru}

Bir suçun manevi unsuru, kast ve taksir başlıkları altında incelenmesi gerekmektedir.

\section{Kast}

Kast, suçun kanuni tanımındaki maddi unsurların bilinmesi ve istenmesi demektir (TCK, m.21/1). Siyasi hakların kullanılmasının engellenmesi suçları da ancak kasten işlenebilen suçlardandır (Tezcan, 2014).

\section{Taksir}

Siyasi hakların kullanılmasının engellenmesi suçlarının taksirle işlenmesi mümkün değildir. Taksirle bu suçun işlenmesinin cezai sorumluluğu söz konusu olabilmesi için özel bir düzenlemenin yapılmış olması gerekmektedir (TCK, m.22/1).

\section{Suçun Özel Görünüş Şekilleri}

Bir suçun özel görünüş şekilleri üç başlık altında incelenir: Teşebbüs, iştirak ve içtima.

\section{Teşebbüs}

TCK m.114/1'de yer alan fiiller ki, -bunlar; bir siyasi partiye üye olmaya veya olmamaya, siyasi partinin faaliyetlerine katılmaya veya katılmamaya, siyasi partiden veya siyasi parti yönetimindeki görevinden ayrılmaya, seçim yoluyla gelinen bir kamu görevine aday olmamaya veya seçildiği görevden ayrılmaya zorlamak amacıyla cebir veya tehdit kullanılması fiilleridir- bu fiilleri gerçekleştirmeye yönelik yapılan cebir veya tehditle suç tamamlanmış olmaktadır. Yani uygulanan cebir veya tehditle kişinin siyasi haklarının engellenmesi şart değildir. Dolayısıyla kişinin siyasi haklarını engellemeye yönelik cebir veya tehditle siyasi haklarının engellenip engellenmemesi önem arz etmemektedir. $\mathrm{Bu}$ bakımdan öğretide 114/1'de yer alan suç tanımına teşebbüs suçu da denilmektedir (Özbek vd, 2015; Tezcan, Erdem ve Önok, 2014).

Her ne kadar madde metninde yer alan seçimlik hareketlerin gerçekleşmesi gerekli olmasa da, bu fiillerin cebir veya tehditle gerçekleşmesi gerektiğinden cebir veya tehditin gerçekleşmesi suçun tam bir teşebbüs suçu olmadığını göstermektedir. Örneğin görevini bırakması için tehdit içeren bir telefon konuşmasına maruz kalan bir belediye başkanının bilahare istifa etmese de, bu suç tamamlanmış olacaktır. Şu halde TCK m.114/1'de yer alan suç, bir teşebbüs suçu olsaydı buna teşebbüs de mümkün olamazdı (Özgenç, 2019). Oysa aynı örnekte, tehditlerin bir mektupla yazılarak gönderilip bilahare mektubun adresine ulaşamayıp geri gelmesi durumunda, 114/1'de yer alan suça teşebbüs söz konusu olabilecektir.

\section{İştirak}

İştirak bakımından söz konusu suç bir özellik arz etmemektedir. Yani herkesin bu suça fail veya şerik sıfatıyla katılması mümkündür. 


\title{
İçtima
}

Cebir ve tehdit, siyasi hakların kullanılmasının engellenmesi suçunun unsurunu oluş̧urduğu için, bileşik suçu düzenleyen TCK m.42 gereği, ayrıca cebir veya tehditten failin cezalandırılması yoluna gidilemeyecektir.

Özel kanunlarda düzenlenen siyasi hakların engellenmesine yönelik cezalandırılan fiiller ile TCK m.114'te yaptırıma bağlanan fiiller arasında benzerlik söz konusu olursa, kanaatimizce özel normun önceliği ilkesi gereği özel normu düzenleyen kanun uygulanacaktır. Bu kapsamda, 2911 sayılı Toplantı ve Gösteri Yürüyüşleri Kanunu'nun 28 -34. maddeleri arasında yaptırıma bağlanan fiiller, TCK m.114'e göre özel norm olarak değerlendirilmelidir (Özgenç, 2019). Mesela, bir siyasi partinin toplantı ve yürüyüş yapmasına cebir veya tehditle engel olma fiili, TCK m.114/1 kapsamında değerlendirilmesi mümkün gözükse de, kanaatimizce 2911 sayılı Kanunun 29. maddesi gereği failin cezalandırılması yoluna gidilmelidir.

Keza 298 sayılı Seçimlerin Temel Hükümleri ve Seçmen Kütükleri Hakkında Kanun'un 148 ve devamı maddelerinde seçim hakkına ve siyasi partilerin faaliyetlerine yönelik bazı fiiller yaptırıma bağlanmıştır. Bu fiiller, TCK m.114'e göre özel norm sayılmalıdır. Mesela, 298 sayılı Kanunun 149. maddesinde bir siyasi partinin seçim propagandasına engel olmak suç olarak düzenlendiğinden TCK m.114 uygulama alanı bulamayacaktır. Özel normun önceliği ilkesi gereği yine 298 sayılı Kanunun 151. maddesinde cebir veya tehditle kişilerin seçim hakkının engellenmesi de yaptırıma bağlandığından TCK m.114 uygulanamayacaktır.

Yargitay ise, burada fikri içtima hükümlerinin uygulanması gerektiğini ifade etmektedir ki, bu görüşe katılmamaktayız:

\begin{abstract}
"Seçim hakkının cebir veya tehdit yoluyla engellenmesi fiilleri bu suç (TCK, m.114) kapsamına girmeyip, 298 sayılı Seçimlerin Temel Hükümleri ve Seçmen Kütükleri Hakkında Kanunun 152. maddesinde ayrıca düzenlenmiştir. Aynı Kanunun 149. maddesinde de, herhangi bir vasıta ile seçim propagandasi toplantısina engel olan veya imkan vermeyecek hareket ve tertiplerle onu ihlal eden kişilerin bu fiilleri yaptırıma bağlanmaktadır. $\mathrm{Bu}$ durumda somut olayın özelliğine göre siyasi partinin faaliyetine seçim döneminde engel olunması durumunda fikri içtima hükümlerine göre hangi maddede öngörülen ceza ağır ise o madde hükümleri uygulanacaktır (Yargitay, 4. Ceza Dairesi, Esas:2014/585, Karar:2016/9881, Karar Tarihi: 12.05.2016).”
\end{abstract}

Burada fikri içtima söz konusu olamaz çünkü aynı hukuki değeri ihlal eden iki suç arasında genel norm-özel norm ilişkisi söz konusu olur. Fikri içtima da ise, farklı hukuki değerlerin ihlal edildiği, farklı suç tanımlarının tek bir fiil ile ihlal edilmesi durumunda söz konusu olmalıdır (TCK, m.44).

TCK'nın 119. maddesi, siyasi hakların kullanılmasının engellenmesi suçunu da kapsayan bazı suçlar için ortak hüküm mahiyetindedir. Bu maddenin ikinci fikrasında, "Bu suçların işlenmesi sırasında kasten yaralama suçunun neticesi sebebiyle ağırlaşmış hallerinin gerçekleşmesi durumunda, ayrıca kasten yaralama suçuna ilişkin hükümler uygulanır" hükmü yer almaktadır. Dolayısıyla siyasi hakların kullanılmasının engellenmesi suçu işlenirken, mesela bir bakanın cebirle istifaya zorlanması sırasında neticesi sebebiyle ağırlaşmış yaralama söz konusu olursa mesela duyularından birinin işlevini sürekli yitirmesi durumunda TCK m.87'ye göre ayrıca cezaya hükmolunacaktır. Şu hâlde, neticesi sebebiyle ağırlaşmış haller yoksa yani kasten yaralamanın temel şekli söz konusuysa burada uygulanan cebir artık siyasi hakların kullanılmasının engellenmesi suçunun unsurunu oluşturacaktır ve bileşik suç söz konusu olacaktır. Ayrıca TCK m.86'dan hüküm tesis edilmeyecektir.

Keza siyasi hakların kullanılmasının engellenmesi fiili, TCK m. 309'da düzenlenen anayasayı ihlal suçunun unsurunu oluşturabilir. Mesela, anayasal düzeni değiştirmeye teşebbüs edilirken kullanılan cebir, pekala seçim yoluyla gelen kamu görevlilerinin görevlerinden ayrılmaya zorlama sayılabilecektir. Dolayısıyla burada anayasayı ihlal fiilinin unsuru olan siyasi hakların kullanılmasının 
engellenmesi fiili söz konusu olacaktır. Başka bir ifadeyle, anayasayı ihlal fiili bir bileşik suç görünümünde olacaktır. Bu durumda, ayrıca TCK m.114'ten ayrıca hüküm tesis edilmeyecektir.

TCK m.114'te düzenlenen fiiller için zincirleme suç hükümlerinin söz konusu olması mümkündür. Failin farklı zamanlarda aynı mağdura karşı söz konusu fiilleri işlemesi durumunda zincirleme suç hükümleri dikkate alınacaktır:

"Sanığın 29 Mart 2009 tarihinde yapılan yerel yönetim seçimlerinde aday olan mağdur ...'ı arayarak adaylıktan çekilmesi yönünde tehdit ettikten 6 dakika sonra aynı amaçla diğer aday mağdur ...'a iletilmek üzere mağdurun akrabalarını arayarak tehdit etmesi şeklinde gerçekleşen olayda, zincirleme suç hükümlerinin uygulanmasında bir isabetsizlik görülmeyerek verilen mahkumiyet kararının Yerel Mahkemece isabetli olarak saptandığı değerlendirilerek ... (Yargıtay, 4. Ceza Dairesi, Esas:2014/585, Karar:2016/9881, Karar Tarihi: 12.05.2016.)."

\title{
Suçun Nitelikli Halleri
}

Siyasi hakların kullanılmasının engellenmesi suçunun nitelikli halleri 5237 sayılı TCK'nın 119. maddesinde düzenlenmiştir. Buna göre bu suçun,

-Silahla (m.119/1(a)),

-Kişinin kendisini tanınmayacak bir hale koyması suretiyle, imzasız mektupla veya özel işaretlerle (m.119/1(b)),

-Birden fazla kişi tarafindan birlikte (m.119/1(c)), (m.119/(d)),

-Var olan veya var sayılan suç örgütlerinin oluşturdukları korkutucu güçten yararlanılarak

-Kamu görevinin sağladığı nüfuz kötüye kullanmak suretiyle (m.119/1(e))

işlenmesi halinde verilecek ceza bir kat artırılırken; bu suçların işlenmesi sırasında kasten yaralama suçunun neticesi sebebiyle ağırlaşmış hallerinin gerçekleşmesi durumunda, ayrıca kasten yaralama suçuna ilişkin hükümler uygulanır (m.119/2).

Eğer somut olayda birden fazla nitelikli hal söz konusu olursa bu durumun temel cezanın belirlenmesinde dikkate alınması gerecektir:

\begin{abstract}
"Suçun silahla ve birden fazla kişi tarafından birlikte işlenmesi karşısında, TCK'nın 61.maddesi gereğince temel ceza belirlenirken, aynı Kanunun 119/1-a ve c maddesindeki iki nitelikli halin gerçekleştiği gözetilerek, alt sınırdan uzaklaşılmak suretiyle ceza tayin edilmesi gerektiğinin gözetilmemesi ... hükmün bozulmasına oy birliğiyle karar verildi (Yargıtay, 4. Ceza Dairesi, Esas:2018/2566, Karar:2018/13339, Karar Tarihi: 04.07.2018).”
\end{abstract}

\section{Soruşturma ve Kovuşturma Rejimi}

Siyasi hakların kullanılmasının engellenmesi suçları, re'sen takip edilen suç tiplerindendir yani şikâyete bağlı değildir (Tezcan, 2014). Bu konuya örnek olarak şu olayı vermek istiyoruz: 31 Mart 2019 tarihinde yapılan yerel seçimler öncesi İstanbul, Ankara, Bursa, Düzce, Niğde ve Balıkesir Belediye Başkanları halka ve basına açık olarak istifalarını vermişlerdir. Bunların arasında en dikkat çekici olanı Ahmet Edip Uğur'un 30.10.2017 tarihli halka açık basın toplantısıdır. Bu toplantıda kendisi şu ifadeleri kullanmıştır:

"Yolsuzluğunuz yok, usulsüzlüğ̈̈nüz yok, başarısızlığınız yok, FETÖ bağlantınız yok ve fakat ailenize, evinize kadar ulaşan baskılar, tehdide varan müdahaleler var. Bu katlanacak bir durum olmanın ötesine geçmiştir. Dolayısıyla siyaset yapma imkânımız maalesef ortadan kaldırılmıştır. Gelinen bu durumda, partimden ve belediye başkanlığı görevimden ayrılma noktasına gelmiş, getirilmiş bulunmaktayım (https://www.youtube.com/watch?v=m8m8lyezsOE, Erişim Tarihi: 20.04.2020).” kullanmıştır:

Bu konuşmayı müteakip aynı gün, bir hükümet yetkilisi basına açık toplantısında şu ifadeleri 
“Öyle bir şey olduğunu düşünmüyorum. Varsa öyle bir şey, bununla ilgili yasal yollar açıktır” (https://www.ntv.com.tr/turkiye/bozdagedip-ugur-tehdit-var-diyorsa-yasal-yollar-aciktir,iBIkKOKT009rTKgRHXcTA, Erişim Tarihi: 20.04.2020)

diyerek kişinin adli mercilere başvurması gerektiğini ifade etmiştir. Oysa re'sen soruşturulması gereken söz konusu fiiller, maddi gerçek bakımından işlendiği sübut bulursa -belediye başkanı istifa etmiş olmasaydı da- "siyasi hakların kullanılmasının engellenmesi suçu"nun işlendiği açıktır. Eğer böyle bir iddia maddi gerçek bakımından sübut bulmaz ise, TCK m.267'de düzenlenen iftira suçundan bir cezai sorumluluk söz konusu olabilecektir.

Keza hüküm aşamasında bu suç için 1 yıl hapis cezasına hükmedilirse, TCK m.50/1(a) göz önünde bulundurularak cezanın adli para cezasına çevrilmesi mümkündür. Keza söz konusu suçtan dolayı iki yıl veya daha az süreli hapis cezasına hükmedilirse, 5271 sayılı Ceza Muhakemesi Kanunu'nun 231. maddesinde düzenlenen "hükmün açıklanmasının geri bırakılması kararı" veya 5237 sayılı Türk Ceza Kanunu'nun 51. maddesinde düzenlenen "hapis cezasının ertelenmesi” kararının da verilmesi mümkündür. Hükmün açıklanmasının geri bırakılması kararı verilirse, sanık hakkında hükmolunan cezanın belirli bir denetim süresi içerisinde sonuç doğurmaması ve denetim süresi içerisinde belirli koşulların yerine getirilmesi durumunda, hükmün sonuç doğurmayacak şekilde ortadan kalkması söz konusuyken; hapis cezasının ertelenmesine karar verilmesi durumunda, belirlenen cezanın ceza infaz kurumunda infaz edilmesinden şartlı olarak vazgeçilmesi söz konusu olacaktır (Özgenç, 2019).

Aynı şekilde söz konusu suç uzlaşma kapsamında kural olarak yer almamaktadır. Çünkü şikayete bağlı değildir ve 5271 sayılı Ceza Muhakemesi Kanunu'nun 253. maddesinde uzlaştırma kapsamında sayılan suç tanımlarından biri de değildir. Fakat CMK m. 253/1(c)'ye göre, "mağdurun veya suçtan zarar görenin gerçek veya özel hukuk tüzel kişisi olması koşuluyla, suça sürüklenen çocuklar bakımından ayrıca, üst sınırı üç yılı geçmeyen hapis veya adli para cezasını gerektiren suçlar" uzlaştırma kapsamında alındığından, sadece suça sürüklenen çocuklar bakımından TCK m.114/1 uzlaştırma kapsamında sayılacaktır.

Keza bu suçta dava zamanaşımı süresi, 8 yıl iken; ceza zamanaşımı süresi 10 yıldır (TCK, m.66/1(e); m.68/1(e)).

\section{Yetkili ve Görevli Mahkeme}

Söz konusu suçları, görmekle görevli mahkeme ise, suçun işlendiği yer asliye ceza mahkemeleridir (26.9.2004 tarih ve 5235 sayılı Adli Yarg1 İlk Derece Mahkemeleri ile Bölge Adliye Mahkemelerinin Kuruluş, Görev ve Yetkileri Hakkında Kanun, m.11).

\section{Sonuç, Tartışma ve Öneriler}

Siyasi haklar anayasalarımızda teminat altına alınan ve kişisel haklardan sonra gelen ve kişinin devlet yönetimine katılımına imkân sağlayan haklardır. Aktif statü hakları veya katılım hakları olarak da adlandırılan bu siyasi hakların hür bir şekilde kullanmasını sağlamak, devletin asli görevlerinden biridir. Türk Ceza Kanunu'nun 114. maddesiyle düzenlenen suç tanımlarında bazı siyasi haklar koruma altına alınmak istenmiştir.

Türk Ceza Kanunu'nda düzenlenen 114. maddesinin başlı̆̆ madde metnine uygun düşmemiştir. Her ne kadar siyasi hakların kullanılmasının engellenmesi ifadesi yer alsa da, madde metninde tüm siyasi haklar koruma altına alınmamıştır. Dolayısıyla Türk Ceza Kanunu'nun 114. maddesinin, madde başlığının belirli siyasi hakların kullanılmasının engellenmesi olarak düzeltilmesi veya suç tanımının genişletilmesi kanaatimizce daha yerinde olacaktır. 
Yargitay'ın siyasi hakların kullanılmasının engellenmesi fiili ile ilgili olarak vermiş olduğu kararlarda, genel norm-özel norm yorumunun yapılacağı yerde, fikri içtima kurallarına göre olayın çözümlenmesi gerektiğine dair düşüncesi Türk ceza hukukun genel hükümleriyle bağdaşmamaktadır. Çünkü fikri içtima kuralları, kanunun farklı suç hükümlerinin tek bir fiil ile ihlal edilmesi durumunda söz konusudur. Dikkat edilirse söz konusu maddede, farklı suç tanımları, farklı hukuki değerleri korumaktadır. Başka bir ifadeyle aynı hukuki değeri koruyan farklı suç tanımları arasında fikri içtima kuralları değil, genel norm-özel norm ilişkisinin varlığını kabul etmek gerekir.

\section{Kaynaklar}

Artuk, M. E., Gökcen, A. ve Yenidünya, A. C. (2014). Ceza hukuku özel hükümler. Ankara: Adalet.

Aydoğdu, Y. (2017). Türk hukukunda siyasi haklar ve siyasi hakların kullanılmasının engellenmesi suçu. Türkiye Barolar Birliği Dergisi,128, 39-72.

Gözler, K. (2017). Insan hakları hukukuna giriş. Bursa: Ekin.

Küçük, A. (2013). Anayasa hukuku. Ankara: Seçkin.

Özbek, V. Ö. (2008). Yeni Türk Ceza Kanunun Anlamı. Ankara: Seçkin.

Özbek, V. Ö., Kanbur, M. N., Doğan, K., Bacaksı,, P. ve Tepe, İ. (2015). Türk Ceza Hukuku genel hükümler. Ankara: Seçkin.

Özgenç, İ. (2019). Türk Ceza Hukuku genel hükümler. Ankara: Seçkin.

Öztürk, B. ve Erdem, M. R. (2013). Uygulamalı ceza hukuku ve güvenlik tedbirleri hukuku. Ankara: Seçkin.

Tezcan, D., Erdem, M. R. ve Önok, R. M. (2014). Teorik ve pratik ceza özel hukuku. Ankara: Seçkin.

Turhan, A. (2013). İnsan hakkı kuşakları arasındaki tamamlayıcılık ilişkisi. İnönü Üniversitesi Hukuk Fakültesi Dergisi, 4(2), 357-378.

Türkçe Sözlük (2017). İstanbul: Türk Dil Kurumu.

Y1lmaz, E. (2011). Hukuk sözlüğ̈̈. Ankara: Yetkin.

Yargitay, 4. Ceza Dairesi, Esas: 2014/585, Karar: 2016/9881, Karar Tarihi: 12.05.2016.

Yargitay, 4. Ceza Dairesi, Esas: 2014/792, Karar: 2016/9880, Karar Tarihi: 12.05.2016.

Yargitay, 4. Ceza Dairesi, Esas: 2018/2566, Karar: 2018/13339, Karar Tarihi: 12.05.2016.

Nergis Televizyonu (2020). AKP Balıkesir Belediye Başkanı istifa konuşması. 20.04.2020 tarihinde $\mathrm{https}: / / \mathrm{www}$. youtube.com/watch?v=m8m8IyezsOE adresinden erişilmiştir.

Nergis Televizyonu (2020). Bozdăg: Edip Ŭgur tehdit var diyorsa yasal yollar açıktır. 20.04.2020 tarihinde https://www.ntv.com.tr/turkiye/bozdagedip-ugur-tehdit-var-diyorsa-yasal-yollaraciktir,iBI-kK0KT0O9rTKgRHXcTA adresinden erişilmiştir. 


\section{Extended Abstract}

\section{Introduction}

Political rights are fundamental rights and freedoms that enable individuals to participate in state administration. As a matter of fact, political rights are also called as "right to participate" or "active status rights". Political rights are basically expressed in the 66th and continuation articles of the 1982 Constitution. Accordingly, the right to choose, be elected and engage in political activities, the right to form a party, to enter and leave the parties, the right to enter public services, the right to home service, the right to petition are among the political rights.

\section{Related Regulation in Turkish Criminal Code}

Political rights are the rights that are guaranteed in our constitutions and come after personal rights and enable the participation of the person in the state administration. It is one of the primary duties of the state to ensure that these political rights, also called active status rights or participation rights, are used freely. In the definitions of the crime regulated by article 114 of the Turkish Penal Code, some political rights were taken under protection.

The title of the article 114 of the Turkish Penal Code did not comply with the text of the article. Although there is an expression of preventing the use of political rights, all political rights are not protected in the article. Therefore, it would be more appropriate in our opinion to correct the 114th article of the Turkish Penal Code as the prevention of the use of certain / certain political rights.

In the decisions made by the Supreme Court regarding the act of preventing the use of political rights, the idea that the incident should be resolved according to the rules of intellectual use, where the general norm-specific norm interpretation will be made, is incompatible with the general provisions of the Turkish criminal law. Because the rules of intellectual use are in question in case of violation of different crime provisions of the law with a single act. Note that different crime definitions protect different legal values. In other words, it is necessary to accept the existence of the general norm-specific norm relationship, not the intellectual interaction rules between different crime definitions that maintain the same legal value.

\section{Conclusion, Discussion and Suggestions}

In the Turkish Penal Code No. 5237, some of the acts against political rights are regulated in the seventh part of the second book of the law, titled "Crimes Against Freedom", of the second part of the second book titled "Special Provisions". In this seventh chapter, certain political rights are protected, not all political rights. According to our opinion, it would be more appropriate to define this definition of crime in the Crimes Against the Nation and the State of the Turkish Penal Code. Because violation of a political right prevents the state from fulfilling its political functions, and therefore there is a crime against the basic order of the state.

All crimes regulated in Article 114 are connected mobile crimes. However, in the crimes regulated in the first paragraph, force or threat must be used against the victim, unlike the second paragraph, it is not possible to commit these crimes with "another illegal behavior", for example, by cheating. However, in the second paragraph, this is broadly possible.

Although the elective actions in the text of the article are not necessary, the realization of the force or threat shows that the crime is not a crime of any attempt, since these actions must take place with force or threat. For example, if a mayor who has been subjected to a telephone conversation with a threat to leave his post will not resign, this crime will be completed. 
As we have stated, unlike the Article 174 of the Turkish Criminal Code numbered 765, which political rights are clearly stated. The uncertainty caused by the term "political rights" left unexplained in the previous arrangement was eliminated. As a matter of fact, the Supreme Court also included the following statements that we took in a decision: "In this legal arrangement, it is different from the 174th article of the Turkish Penal Code No. 765, which was the previous legal regulation. It is clearly stated which rights are qualified as political rights. The uncertainty caused by the phrase "political rights" left unexplained in the previous regulation has been eliminated."

In summary, there is a protection of political rights at an equal level with Law No. 765 . Because there is no clarity in the legal definition about which rights will be qualified as political rights. Essentially, this is in line with the principle of certainty and the principle of legality in crime and punishment. In other words, in accordance with these principles that constitute the assurance function of criminal law, the legal definition of crime must be clear and specific. In summary, binding of unlawful acts to penal sanctions constitutes a violation of the lawfulness principle. 